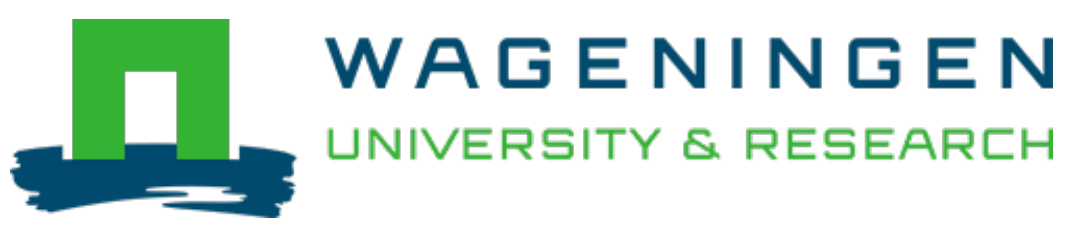

\title{
A deeper insight into the characteristics of double-layer oil-in-water emulsions stabilized by Persian gum and whey protein isolate
}

\author{
Journal of Dispersion Science and Technology
}

Hadian, Mohammad; Labbafi, Mohsen; Hosseini, Seyed Mohammad Hashem; Safari, Mohammad; Vries, Renko

https://doi.org/10.1080/01932691.2020.1816178

This article is made publicly available in the institutional repository of Wageningen University and Research, under the terms of article $25 \mathrm{fa}$ of the Dutch Copyright Act, also known as the Amendment Taverne. This has been done with explicit consent by the author.

Article 25 fa states that the author of a short scientific work funded either wholly or partially by Dutch public funds is entitled to make that work publicly available for no consideration following a reasonable period of time after the work was first published, provided that clear reference is made to the source of the first publication of the work.

This publication is distributed under The Association of Universities in the Netherlands (VSNU) 'Article $25 \mathrm{fa}$ implementation' project. In this project research outputs of researchers employed by Dutch Universities that comply with the legal requirements of Article $25 \mathrm{fa}$ of the Dutch Copyright Act are distributed online and free of cost or other barriers in institutional repositories. Research outputs are distributed six months after their first online publication in the original published version and with proper attribution to the source of the original publication.

You are permitted to download and use the publication for personal purposes. All rights remain with the author(s) and / or copyright owner(s) of this work. Any use of the publication or parts of it other than authorised under article $25 \mathrm{fa}$ of the Dutch Copyright act is prohibited. Wageningen University \& Research and the author(s) of this publication shall not be held responsible or liable for any damages resulting from your (re)use of this publication.

For questions regarding the public availability of this article please contact openscience.library@,wur.nl 


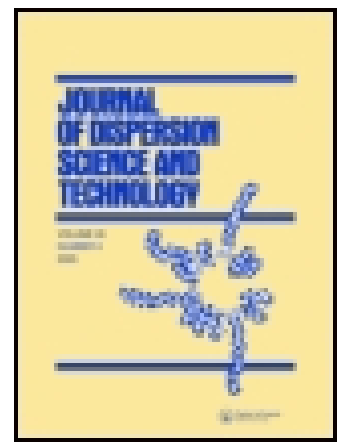

Journal of Dispersion Science and Technology

\title{
A deeper insight into the characteristics of double- layer oil-in-water emulsions stabilized by Persian gum and whey protein isolate
}

\author{
Mohammad Hadian, Mohsen Labbafi, Seyed Mohammad Hashem \\ Hosseini, Mohammad Safari \& Renko de Vries
}

To cite this article: Mohammad Hadian , Mohsen Labbafi, Seyed Mohammad Hashem Hosseini , Mohammad Safari \& Renko de Vries (2020): A deeper insight into the characteristics of doublelayer oil-in-water emulsions stabilized by Persian gum and whey protein isolate, Journal of Dispersion Science and Technology, DOI: 10.1080/01932691.2020.1816178

To link to this article: https://doi.org/10.1080/01932691.2020.1816178

\section{曲 Published online: 09 Sep 2020.}

Submit your article to this journal $2 \pi$

Џll Article views: 47

Q View related articles $\sqsubset$

View Crossmark data $\widetilde{ }$ 


\title{
A deeper insight into the characteristics of double-layer oil-in-water emulsions stabilized by Persian gum and whey protein isolate
}

\author{
Mohammad Hadiann ${ }^{\mathrm{a}, \mathrm{b}}$, Mohsen Labbafi ${ }^{\mathrm{a}}$, Seyed Mohammad Hashem Hosseini ${ }^{\mathrm{c}}$, Mohammad Safari ${ }^{\mathrm{a}}$, and \\ Renko de Vries ${ }^{b}$ \\ ${ }^{a}$ Department of Food Science and Technology, Razi Food Chemistry Lab, College of Agriculture and Natural Resources, University of Tehran,

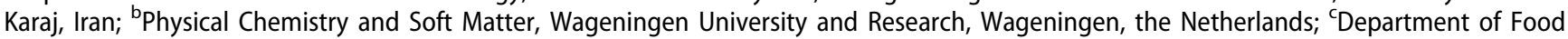 \\ Science and Technology, School of Agriculture, Shiraz University, Shiraz, Iran
}

\begin{abstract}
Whey protein isolate (WPI) is an excellent emulsifier. However, WPI-stabilized emulsions tend to flocculate at $\mathrm{pH}$ values close to their isoelectric point. In this work, a layer by layer (LBL) technique was used to develop double layer oil in water emulsions using a mixture of WPI and water-soluble fraction of Persian gum (WSPG). Polysaccharide concentration and $\mathrm{pH}$ were found to have a major impact on the stability of the final system. At a constant total biopolymer concentration, increasing the amount of WSPG significantly $(p<0.05)$ improved the emulsion physical stability. An appropriate stability was obtained at $0.5 \mathrm{wt} \% \mathrm{WPI}, 1 \mathrm{wt} \% \mathrm{WSPG}$, and pH 5.0. At high ionic strength, the emulsions became unstable with a higher sensitivity to $\mathrm{CaCl}_{2}$ than $\mathrm{NaCl}$. Confocal laser scanning microscopy and zeta-potential measurements confirmed the electrostatic adsorption of WSPG onto the WPI-stabilized oil droplets. The results of interfacial tension and dilatational rheology measurements revealed a slight decrease in the interfacial tension after the adsorption of WSPG as the second layer and a predominantly elastic behavior $\left(E^{\prime}>E^{\prime \prime}\right)$, at the interface especially at $\mathrm{pH}$ 5.0. The results showed that WSPG is an appropriate candidate for improving the physical stability of WPI-stabilized emulsions at $\mathrm{pH}$ values close to isoelectric point.
\end{abstract}

\section{GRAPHICAL ABSTRACT}
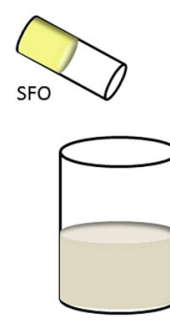

WPI

SFO

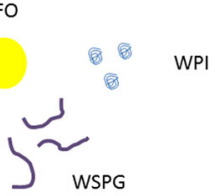

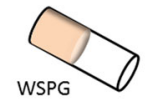

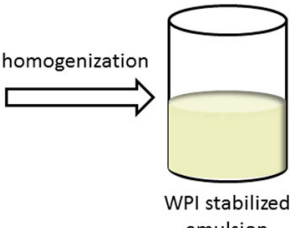

Stirring and $\mathrm{pH}$

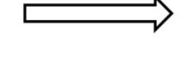

emulsion

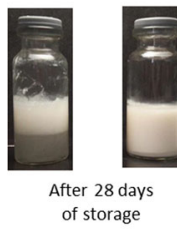
adjustment to 5.0
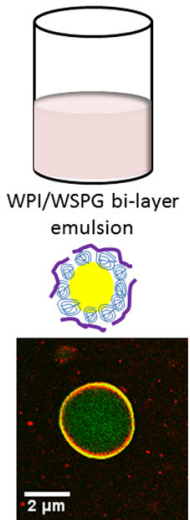

ARTICLE HISTORY

Received 7 May 2020

Accepted 16 August 2020

\section{KEYWORDS}

Multilayer emulsion; Persian gum; whey protein isolate; electrostatic deposition; dilatational rheology

\section{Introduction}

Emulsions are thermodynamically unstable systems. Kinetically stable emulsions can be obtained by using one or more suitable surface active ingredients (emulsifiers), as well as appropriate droplet size distributions. ${ }^{[1]}$ The emulsifier choice is determined by price, availability, ease of application and compatibility with other components. In addition, the nature of emulsifiers and their behavior under the effect of $\mathrm{pH}$, heating, freezing and ionic strength also play a role in their selection. ${ }^{[1,2]}$ Proteins, polysaccharides and phospholipids are common emulsifiers in the food industry. ${ }^{[3]}$ Emulsions stabilized by only proteins are often 
plagued by instability toward flocculation for certain values of $\mathrm{pH}$, and at higher ionic strengths. A strategy to overcome these limitations is the creation of interfacial multilayers around the oil droplets, by adsorbing alternate layers of proteins and oppositely charged polysaccharides, forming a thick layer at the interface. ${ }^{[4]}$ In this technique, the first layer (protein) is adsorbed to the interface during homogenization, producing the primary emulsion. In the next step, the polysaccharide is added to the emulsion to form double layer emulsion. As a next step, usually the $\mathrm{pH}$ is adjusted, to induce the electrostatic attraction between protein and polysaccharide. It is also be possible to add more than two layers with this procedure for achieving different properties and behaviors of the emulsion. ${ }^{[5]}$ Many studies have previously reported the utilization of various protein/polysaccharide pairs in development of multilayer emulsions. ${ }^{[6-11]}$

Whey proteins have been often used as emulsifiers due to their ability to stabilize $\mathrm{O} / \mathrm{W}$ emulsions, ${ }^{[12-17]}$ but their interaction with Persian gum at oil-water interfaces has not yet been studied in much detail. Persian gum (PG) is a natural exudate of wild almond trees (Amygdalus scoparia Spach) which is collected from the bark of the trees especially from west parts of Iran. ${ }^{[18]} \mathrm{PG}$ is widely used as a traditional medicine, a toothache cure, an appetite stimulant and a bladder stone crusher. ${ }^{[19,20]}$ PG consists of both water-soluble $(30 \mathrm{wt} \%)$ and water-insoluble $(70 \mathrm{wt} \%)$ fractions with slight variations in the ratio depending on the plant geographical region. ${ }^{[20]}$ Iran's annual production for this gum exceeds 400 metric tons. ${ }^{[21]}$

Some physicochemical properties and the composition of three types of PG were studied. ${ }^{[22]}$ Some studies on the ability of water-soluble fraction of PG to form electrostatic complexes with WPI have already been performed by Hadian et al. ${ }^{[19,23]}$ and Khalesi et al. ${ }^{[24]}$ Complexes of PG and $\beta$-lactoglobulin have also been used for stabilizing $\mathrm{O} / \mathrm{W}$ emulsions and it was observed that the mixing ratio and $\mathrm{pH}$ values play a crucial role in determining emulsion stability enhancement. ${ }^{[25]}$ In another study, the ability of double layer emulsions prepared by WPI and water soluble fraction of PG (WSPG) for improving the oxidative stability of fish oil was explored. It was concluded that an increase in the WSFG:WPI mixing ratio increased the physical and chemical stability of emulsions. ${ }^{[26]}$ In a comparison of the emulsifying properties of PG and gum Arabic, it was concluded that PG could produce more stable emulsions than gum Arabic. $^{[24]}$ Considering the good availability of PG and attractive food functional properties, we conclude that PG could be an interesting alternative or substitute for gum Arabic in many cases.

To the best of our knowledge there are only a few preliminary studies on WPI/WSPG double layer emulsions, in which primary WPI-stabilized emulsion droplets are coated with WSPG in a separate step. Therefore, we here comprehensively characterize WPI/WSPG double layer emulsion stability and its dependence on $\mathrm{pH}$, biopolymer concentration, ionic strength, ion type, and storage time, using confocal imaging and interfacial rheology to obtain a detailed insight into the WPI/WSPG layers at the oil-water interface.

\section{Materials and methods}

\subsection{Materials}

Whey protein isolate (WPI) was obtained from Davisco Foods International Inc. (Eden Prairie, MN, USA), with a composition of $97.8 \%$ protein, $2.0 \%$ ash, $0.2 \%$ fat (dry weight basis) and $4.6 \%$ moisture (wet weight basis). Persian gum (PG) in a powdered and purified form was a gift by Dena Emulsion Company (Shiraz, Iran). The powder composition (wt\%) was $89 \%$ carbohydrate, $0.5 \%$ protein $(\mathrm{N}$ $\mathrm{x} 6.38), 6.70 \%$ moisture, and $3.63 \%$ ash.

Pure sunflower oil (SFO) was purchased from Narges Shiraz Oil Co. (Shiraz, Iran). All other chemicals were of analytical grade and purchased from Sigma-Aldrich Chemical Co. (Missouri, USA). Double-distilled water (DDW) was used to prepare all solutions.

\subsection{Fractionation of Persian gum}

The dispersion of PG (2.5 wt\%) was prepared by magnetic stirring at $600 \mathrm{rpm}$ at $25^{\circ} \mathrm{C}$ for $10 \mathrm{~h}$ and kept at $4{ }^{\circ} \mathrm{C}$ overnight for complete hydration. The sample was centrifuged at $11,000 \mathrm{~g}$ at $25^{\circ} \mathrm{C}$ for $1 \mathrm{~h}$. Water-soluble fraction of PG (WSPG) was precipitated from supernatant by ethanol addition to reach an ethanol concentration of $70 \%$. The precipitates were lyophilized and milled to a fine powder.

\subsection{Preparation of multilayer emulsions}

Stock solutions of WPI ( $2 \mathrm{wt} \%)$ and WSPG (3wt\%) were prepared separately and kept overnight on a stirrer at room temperature for complete hydration. In order to avoid microbial activity, sodium azide $(0.03 \mathrm{wt} \%)$ was added to these dispersions. Primary coarse emulsion ( $1 \mathrm{wt} \% \mathrm{WPI}$, and $10 \mathrm{wt} \% \mathrm{SFO}$ ) was prepared at $\mathrm{pH} 7.0$ by the dropwise addition of oil into WPI solution on a stirrer, followed by homogenizing at $15,000 \mathrm{rpm}$ for $4 \mathrm{~min}$ (Ultra-Turrax, T25 basic, IKA, Staufen, Germany). Fine emulsion was prepared using a high pressure homogenizer (Homolab 2.2, FBF Italia $(\mathrm{C}$, Parma, Italy) at $50 \mathrm{MPa}$ for five passes. To prepare double layer emulsions, WSPG solution and DDW were added to the WPI-stabilized primary fine emulsion so that to reach different WSPG concentrations $(0.1-1.5 \mathrm{wt} \%)$ and constant WPI $(0.5 \mathrm{wt} \%)$ and SFO (5 wt\%) content. The $\mathrm{pH}$ of samples was adjusted using $\mathrm{HCl}(0.5 \mathrm{M})$ and then stirred for $30 \mathrm{~min}$.

\subsection{Droplet size and zeta potential}

Droplet size and zeta potential analyses were performed using particle size analyzer (Nanopartica SZ-100, Horiba, Kisshoin, Japan). All emulsions were diluted (1:200) with appropriate buffer solutions at the same $\mathrm{pH}$. Measurements were done at room temperature. Diluted emulsions were shaken before being transferred into cuvettes or capillary cells. Duplicate samples along with three measurements were considered to ensure repeatability of the analysis. 


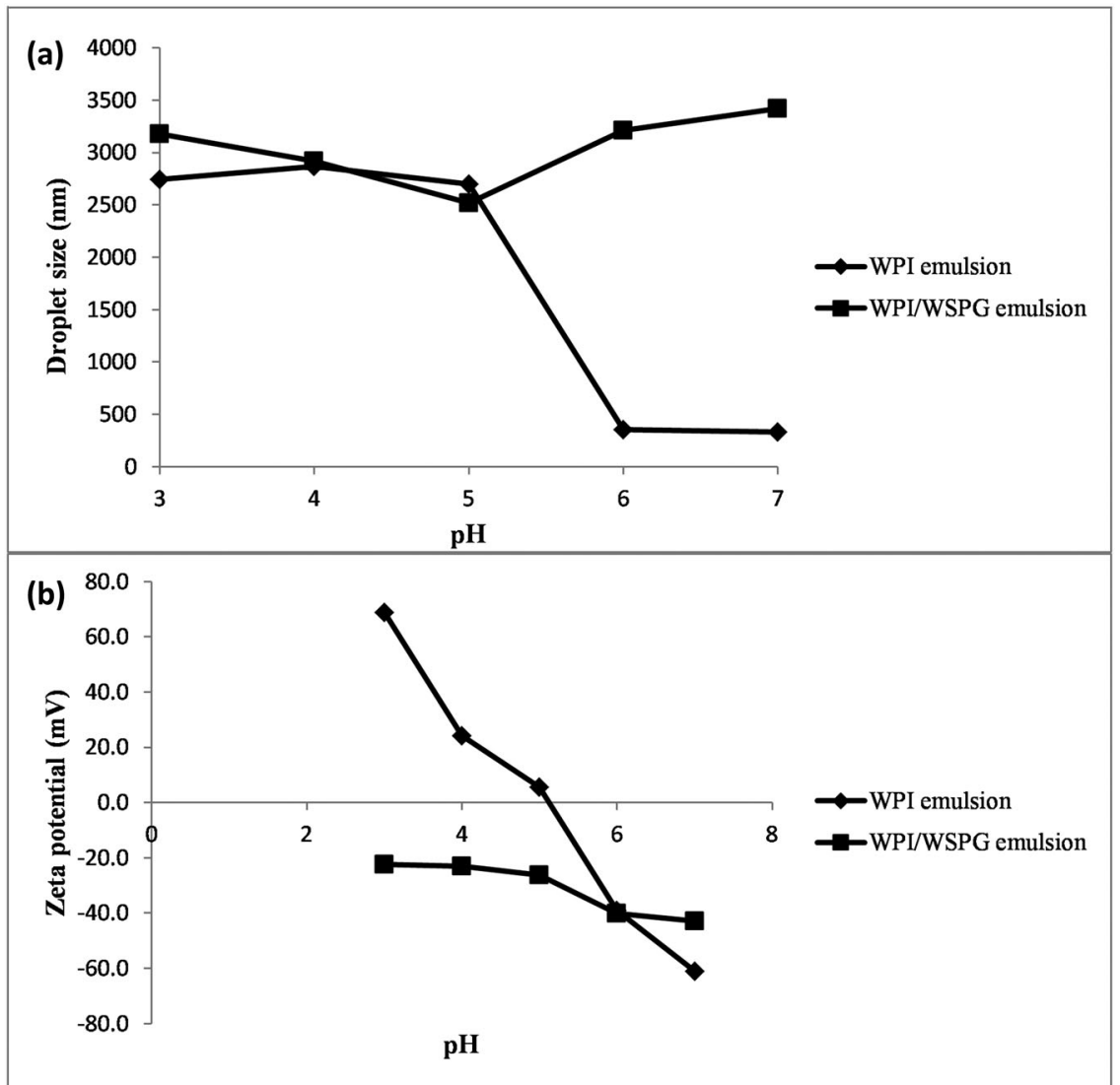

Figure 1. Effect of $\mathrm{pH}$ on (a) droplet size and (b) zeta-potential of WPI emulsions (1 wt $\%$ WPI and $10 \mathrm{wt} \%$ oil) and WPI/WSPG emulsions (0.5 wt $\%$ WPI, 5 wt $\%$ oil, $1 \mathrm{wt} \%$ WSPG).

\subsection{Creaming stability}

Emulsions were stored in sealed glass tubes and kept for 4 weeks at room temperature. The physical stability of emulsions was monitored visually and through measuring creaming index (CI) every seven days. CI was considered as the height of serum layer $\left(\mathrm{H}_{\mathrm{S}}\right)$ divided by the total height of the emulsions $\left(\mathrm{H}_{\mathrm{E}}\right)$ (Equation (1)). Therefore, lower amounts of $\mathrm{CI}$ indicated more stability in the emulsion. ${ }^{[27]}$

$$
\mathrm{CI}(\%)=100 \times\left(\mathrm{H}_{\mathrm{S}} / \mathrm{H}_{\mathrm{E}}\right)
$$

\subsection{Effect of $p H$}

The effect of $\mathrm{pH}$ on emulsion stability was observed by adjusting the $\mathrm{pH}$ values in a range from 7.0 to 3.0 using $\mathrm{HCl}$ solutions while stirring for $30 \mathrm{~min}$. After stirring, the $\mathrm{pH}$ was checked and readjusted to the required point if needed.

\subsection{Effect of ionic strength}

Different amounts of $\mathrm{NaCl}$ and $\mathrm{CaCl}_{2}$ were separately added to double layer emulsions prepared at $0.5 \mathrm{wt} \% \mathrm{WPI}, 1 \mathrm{wt} \%$ WSPG, and $5 \mathrm{wt} \%$ SFO (adjusted to $\mathrm{pH} 5.0$ ) to reach salt concentrations ranging from 0 to $300 \mathrm{mM}$. The emulsion samples were stirred for $1 \mathrm{~h}$ after the salt addition. Droplet size, zeta potential, and CI were then studied.

\subsection{Confocal laser scanning microscopy (CLSM)}

Confocal imaging was performed at room temperature using a laser scanning confocal microscope (Zeiss Axiovert $200 \mathrm{M}$, Carl Zeiss, Oberkochen, Germany) equipped with a $20 \times$ objective. $2 \mathrm{~mL}$ of emulsion was stained with $0.1 \mathrm{~mL}$ Nile Red solution $(1 \mathrm{mg} / \mathrm{mL}$ in ethanol) and $0.1 \mathrm{~mL}$ nile blue $(10 \mathrm{mg} / \mathrm{mL}$ in ethanol) to dye the oil and protein, respectively. For staining the WSPG, 5-Carboxyfluorescein $\mathrm{N}$-succinimidyl ester was used which was first dissolved in $10 \mathrm{mg} /$ $\mathrm{mL}$ dimethyl sulfoxide and stirred for $1 \mathrm{~h}$, then added to the WSPG solution and mixed for $4 \mathrm{~h}$. In order to remove the excess dye, the stained solution was filtrated by $15 \mathrm{kDa}$ centrifugal filters $\left(\right.$ Amicon $^{(}{ }^{\circ}$, Merk Millipore Ltd, Tullagreen, Carrigtwohill, Cork, Ireland). Nile blue was excited at 633 using $\mathrm{HeNe}$ laser and then the emitted light was collected at 660-750 nm. Nile red and the 5-Carboxyfluorescein $\mathrm{N}$-succinimidyl ester dye were excited at $488 \mathrm{~nm}$ by Argon laser and the emission was detected at $520-620 \mathrm{~nm}$ making them show the same color in the images.

\subsection{Interfacial tension}

To study the interfacial tension and dilatational rheology, a drop tensiometer (Teclis, Longessaigne, France) was used and directed with Windrop 2015 software. The glass cuvette of $25 \mathrm{~mL}$ (Hellma-analytics) was supplied with a single-phase exchange instrument to exchange the continuous phase; when 
moving from one solution to the next, the cuvette was rinsed with DDW five times its volume. A syringe with a U-shaped needle was used for injecting the oil inside the water-phase solution in the cuvette. The interfacial tension $(\gamma)$ was determined based on the Young-Laplace equation. ${ }^{[28]}$

WPI solution (WPI, $0.1 \mathrm{~g} / \mathrm{L}$ in $10 \mathrm{mM}$ phosphate buffer $\mathrm{pH}$ 7.0) was placed in the cuvette and oil droplet with a volume of $20 \mu \mathrm{L}$ was delivered by the $\mathrm{U}$-shaped needle. Interfacial tension measurements were performed at room temperature for at least $2 \mathrm{~h}$ to let a proper adsorption take place. Consequently, before introducing the WSPG sample, the cuvette was exchanged with buffer at $\mathrm{pH} 7.0$ to wash out the non-adsorbed WPI. To make the two layer system, the WSPG solution $(0.1 \mathrm{~g} / \mathrm{L}$ in $10 \mathrm{mM}$ buffer $\mathrm{pH} 7.0$ or 5.0$)$ was exchanged through the cuvette. After $1 \mathrm{~h}$, the continuous phase was again rinsed with $\mathrm{pH} 5.0$ buffer. A single run with only DDW in the cuvette was also done just as a baseline for better understanding the interfacial tension changes. Oscillation was carried out at a frequency of $0.01 \mathrm{~Hz}$ with amplitude sweeps $\left(\triangle A / A_{0}\right)$ of $5 \%, 10 \%, 15 \%, 20 \%, 25 \%$, and $30 \%$ at room temperature. The dilatational elastic and viscous moduli $\left(E^{\prime}\right.$ and $\left.E^{\prime \prime}\right)$ were obtained from the measured dynamic interfacial tension responses.

\subsection{Statistical analysis}

The results obtained in this work were reported as mean\pm standard deviation. The statistical analyses were performed using SPSS version 16 for Windows program (SPSS Inc., Chicago, IL, USA) to determine the significant difference between means $(\mathrm{p} \leq 0.05)$ using a one-way ANOVA test.

\section{Results and discussion}

\subsection{Effect of pH on droplet size, zeta potential and stability of emulsions}

First we consider the reference WPI-only stabilized emulsions. Figure 1 shows the changes in the droplet size, and zeta potential of both monolayer and bilayer emulsions as a function of $\mathrm{pH}$. As can be seen in Figure 1, the WPI-stabilized monolayer emulsion was stable at $\mathrm{pH}$ 6.0-7.0 with a relatively small droplet size, and large negative zeta potential values. The emulsion was highly unstable at $\mathrm{pH} 5.0$ mainly due to the proximity of emulsion $\mathrm{pH}$ to the $\mathrm{pI}$ of WPI. Previous studies reported the same results. ${ }^{[29]}$ Globular proteins form a relatively thin layer around the oil droplets and electrostatic repulsion is the main mechanism of stabilization. Therefore, at $\mathrm{pH}$ close to $\mathrm{pI}$, the electrostatic repulsion was reduced leading to the aggregation of protein-coated oil droplets. ${ }^{[30]}$

To prepare double layer emulsions, WSPG solution was added to WPI-stabilized primary emulsions. In contrast to WPI-stabilized monolayer emulsions, the bilayer emulsions were unstable at $\mathrm{pH} 6.0-7.0$ but when decreasing the $\mathrm{pH}$ to 5.0 , they showed high stability. Since both WPI and WSPG are negatively charged at $\mathrm{pH}$ values of $\mathrm{pH} 6.0-7.0,{ }^{[19]}$ depletion flocculation is likely the main reason behind the
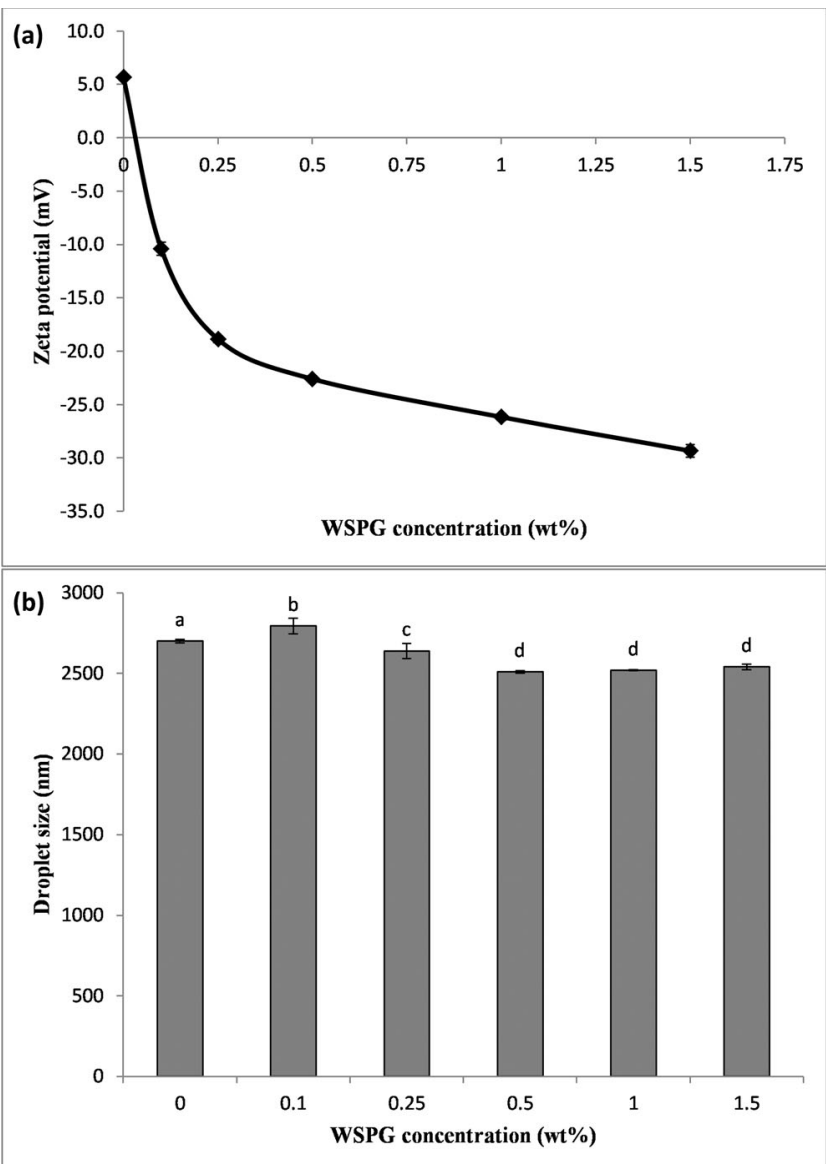

Figure 2. Effect of PG concentration on (a) z-potential and (b) droplet size of emulsions (0.5 wt\% WPI, $5 \mathrm{wt} \%$ oil, $0.1-1.5 \mathrm{wt} \% \mathrm{WSPG}$ ) at $\mathrm{pH} 5.0$.

observed instability induced by WSPG. ${ }^{[5,26,31]}$ Moreover, only low amounts of WSPG were adsorbed to WPI layers at $\mathrm{pH}$ 6.0-7.0 (as discussed later). Hence, at $\mathrm{pH}$ values of 6.0-7.0, the negatively charged WPI-coated oil droplets did not interact with the negatively charged WSPG.

Hadian et al. ${ }^{[23]}$ reported that the electrostatic attraction between WPI and WSPG starts at $\mathrm{pH} \approx 5.3$, where the net charge of protein is still negative. The presence of positive charge patches (i.e., localized regions of basic amino acids) and the ability of proteins to regulate their charge at $\mathrm{pH}$ values close to $\mathrm{pI}$ could lead to electrostatic interactions at $\mathrm{pH}$ values slightly above the $\mathrm{pI}$ of protein. ${ }^{[32-34]}$ In this way, both electrostatic and steric repulsion contribute to the stability of the negatively charged WPI/WSPG bilayer emulsions at $\mathrm{pH}$ 5.0. Thus, development of bilayer emulsions is an appropriate strategy to improve the stability of proteinstabilized emulsions at $\mathrm{pH}$ values close to protein's $\mathrm{pI}$.

At still lower values of the $\mathrm{pH}(\mathrm{pH}$ values $3.0-4.0)$, the addition of WSPG led to flocculation of WPI stabilized emulsion droplets, most likely due to bridging of negatively charged WSPG between multiple droplets started to occur. As a result, flocs were formed as the droplets moved closer and destabilization was initiated in the system with some considerable changes in the droplet size. Similar behavior has also been reported earlier. ${ }^{[8,26,35,36]}$

The zeta potential of WPI-stabilized monolayer emulsions went from highly negative $(-60 \mathrm{mV}$ at $\mathrm{pH}$ 7.0) to highly 


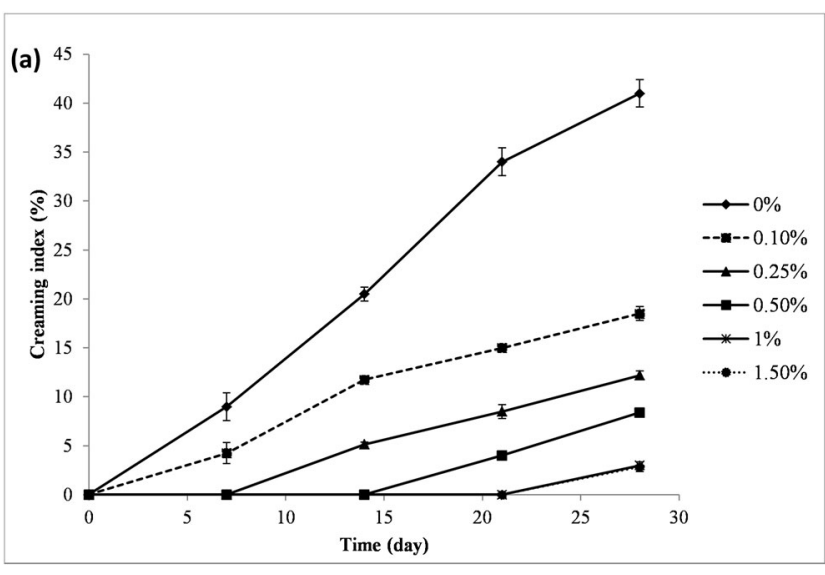

(b)
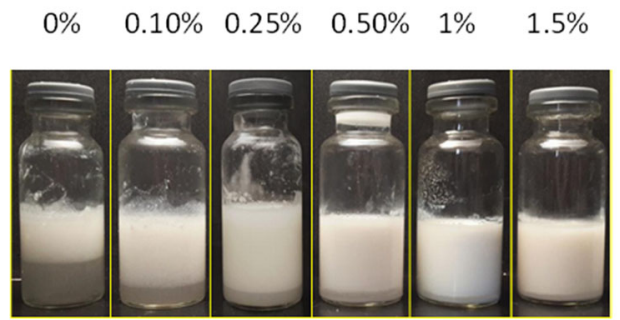

Figure 3. (a) Influence of WSPG concentration on creaming index of emulsions ( $0.5 \mathrm{wt} \%$ WPI, $5 \mathrm{wt} \%$ oil, $0.1-1.5 \mathrm{wt} \%$ WSPG) during 28 days of storage and (b) visual appearance of the WPI/WSPG-stabilized emulsions stored at room temperature $\left(25^{\circ} \mathrm{C}\right)$ after 28 days.

positive $(+69 \mathrm{mV}$ at $\mathrm{pH} 3.0)$ for the primary emulsion. This was a result of high $\mathrm{H}^{+}$concentration at $\mathrm{pH}<\mathrm{pI}$, where the amino groups are positively charged $\left(-\mathrm{NH}_{3}{ }^{+}\right)$and low $\mathrm{H}^{+}$concentration at $\mathrm{pH}>\mathrm{pI}$, where the carboxyl groups are negatively charged $\left(-\mathrm{COO}^{-}\right) \cdot{ }^{[30]}$ In contrast, the zeta potential of the WPI/WSPG samples was negative at all studied $\mathrm{pH}$ values, in which the magnitude increased from $-22 \mathrm{mV}$ at $\mathrm{pH} 3.0$ to $-43 \mathrm{mV}$ at $\mathrm{pH}$ 7.0. These measurements clearly demonstrated that WSPG molecules were adsorbed on the surface of WPI covered droplets at low $\mathrm{pH}$ values. The zeta potential values at $\mathrm{pH}$ above the $\mathrm{pI}$ of WPI (where both WPI and WSPG have a net negative charge) indicated that under these conditions still some electrostatic attraction occurs, most likely between local positively charged patches on the WPI molecules and negatively charged groups of the WSPG molecules. ${ }^{[37]}$ From these results we conclude that WSPG can protect WPI-stabilized emulsions from flocculation at $\mathrm{pH}$ 5.0. This was subjected to more detailed studies in the following sections.

\subsection{Effect of polysaccharide concentration on droplet size, zeta potential and emulsion stability}

We start by considering in more detail the effect of the concentration of WSPG on emulsion stability enhancement at $\mathrm{pH}$ 5.0. Different concentrations of WSPG were added to WPI stabilized emulsions, followed by $\mathrm{pH}$ adjustment to $\mathrm{pH}$ 5.0. Figure 2 shows the average droplet size and zeta potentials of different double layer emulsions prepared from WPI $(0.5 \mathrm{wt} \%)$, SFO ( $5 \mathrm{wt} \%)$, and WSPG $(0.1-1.5 \mathrm{wt} \%)$. WPI-stabilized monolayer emulsions were stable at $\mathrm{pH}$ 7.0. However, at pH 5.0, they were unstable and flocculated due
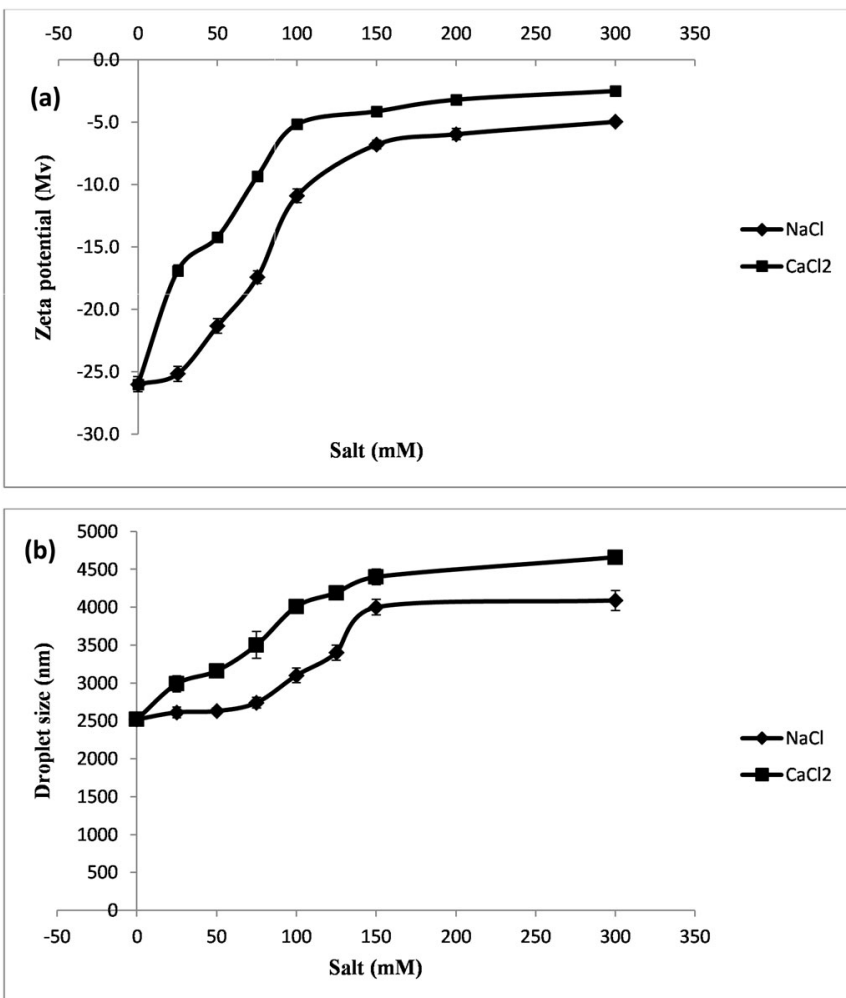

Figure 4. Effect of ionic strength on (a) zeta potential and (b) droplet size of WPI/WSPG emulsions ( $0.5 \mathrm{wt} \% \mathrm{WPI}, 5 \mathrm{wt} \%$ oil, $1 \mathrm{wt} \% \mathrm{WSPG}$ ) at $\mathrm{pH} 5.0$.

to the attraction between WPI-coated emulsion droplets near the WPI isoelectric point $(\mathrm{pH} \approx 5.2)$. When the WSPG solution was added to the system at relatively low concentration $(0.1 \mathrm{wt} \%)$ a slight increase in the mean droplet size was observed suggesting some bridging flocculation of emulsion droplets only partially covered by WSPG. ${ }^{[5]}$ When increasing the WSPG concentration, the droplet size decreased and the zeta potential of the samples became negative due to adsorption of the negatively charged polysaccharide molecules. The stability of the emulsions also increased, suggesting that at these higher concentrations, the emulsion droplets were fully coated with WSPG, such that flocculation no longer occurred.

Droplets of the primary emulsions at $\mathrm{pH} 5.0$ revealed a small positive charge due to some protonation of the amino groups $\left(-\mathrm{NH}_{3}{ }^{+}\right)$in WPI just below its isoelectric point. By adding the polysaccharide to the system, at low concentrations, this small positive charge was neutralized by the WSPG; whereas, at higher concentrations, the zeta potential of the emulsion droplets becomes increasingly more negative.

Flocculation of emulsion droplets can be quantified in terms of the creaming index (CI). ${ }^{[38]}$ Changes in the CI of double layer emulsions, prepared at different WSPG concentrations, during $28-\mathrm{d}$ storage at room temperature are shown in Figure 3a.

Phase separation was observed in the monolayer emulsion stabilized with WPI ( $\mathrm{pH} 7.0)$ at the first week of storage and the CI reached $41 \%$ at the end of storage. WSPG had a considerable effect on the physical stability of the emulsions. At low concentrations of WSPG (0.1 and 


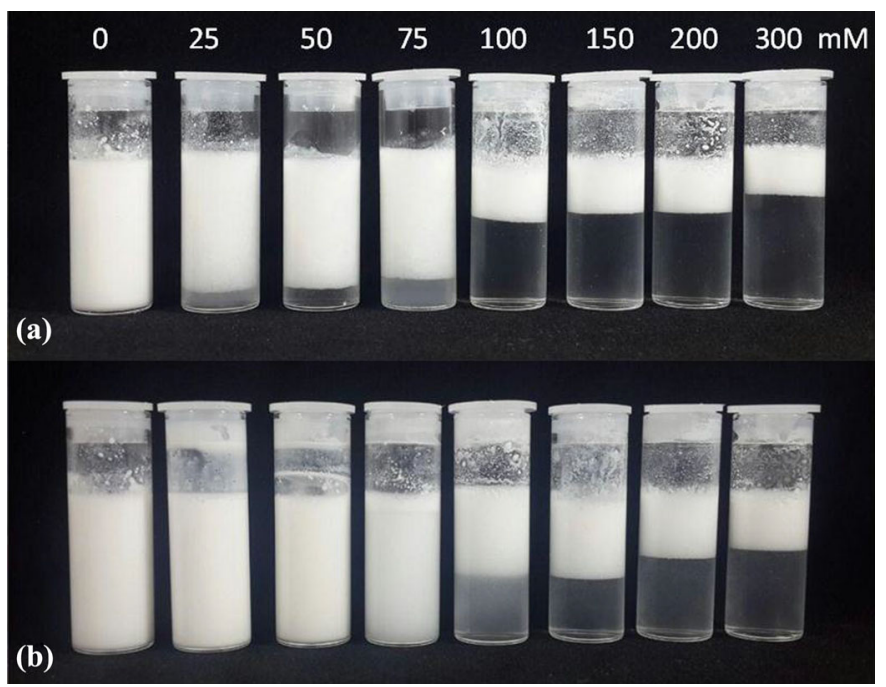

Figure 5. Photographs of emulsions containing (a) $\mathrm{CaCl}_{2}$ and (b) $\mathrm{NaCl}(0-300 \mathrm{mM})$.

$0.25 \mathrm{wt} \%)$, phase separation was observed during the first two weeks of storage, which was attributed to insufficient amounts of polysaccharide molecules to fully cover the emulsion droplets, allowing for bridging flocculation to accelerate creaming. ${ }^{[31]}$ The CI significantly decreased as the WSPG concentration increased; most likely since at these higher concentrations, the WPI-stabilized oil droplets were sufficiently covered by negatively charged WSPG molecules to result in strong steric and electrostatic repulsion between droplets. Emulsions containing $1 \mathrm{wt} \%$ and $1.5 \mathrm{wt} \%$ of WSPG were the most stable samples, showing no noticeable changes in visual appearance during 3 weeks of storage. In addition to the electrostatic repulsion among negatively charged droplets, the increase in the viscosity of continuous phase induced by non-adsorbed (excess) polysaccharide molecules may also contribute to the increased emulsion stability at high WSPG concentrations.

Pictures of the samples shown in Figure $3 \mathrm{~b}$ highlight that the boundary between the serum layer at the bottom and the cream layer on the top was not completely sharp due to the cloudy serum. This could indicate that the system was not completely flocculated, or in other words, that non-flocculated droplets were also present. In general, serum with a cloudy appearance indicates the existence of suspended individual droplets while, emulsion forming a transparent serum phase during their phase separation indicates a much greater extent of droplet flocculation. ${ }^{[39]}$

\subsection{Effect of ion type and ionic strength on zeta potential and emulsion stability}

Food emulsions may have different salt contents, hence we also considered the influence of ionic strength on the double layer emulsions. Figure 4 shows the effect of different salt concentrations on the droplet size and zeta potential of bilayer emulsions formulated with $0.5 \mathrm{wt} \%$ WPI, $1 \mathrm{wt} \%$ WSPG, and $5 \mathrm{wt} \% \mathrm{SFO}$ at $\mathrm{pH}$ 5.0. The WPI-stabilized monolayer emulsion was unstable to aggregation in the presence of salt (data not shown). The bilayer emulsion

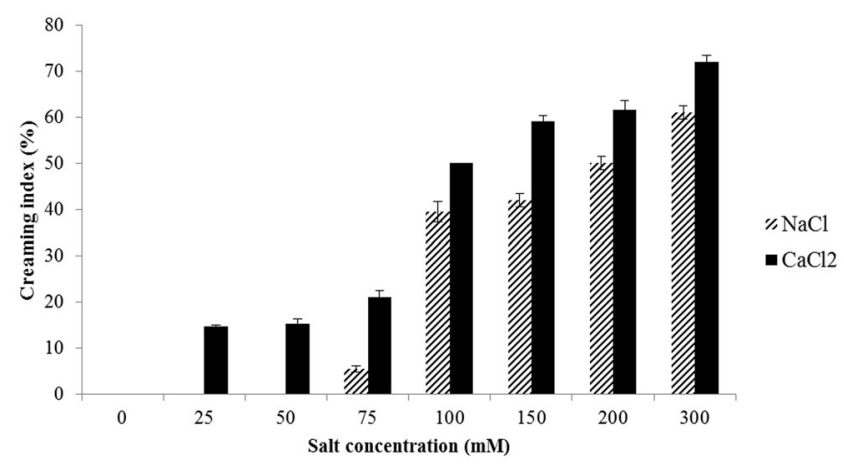

Figure 6. Effect of ionic strength on creaming index of WPI/WSPG emulsions (0.5 wt $\%$ WPI, $5 \mathrm{wt} \%$ oil, $1 \mathrm{wt} \%$ WSPG) at pH 5.0.

remained stable at $\mathrm{NaCl}$ concentration up to $50 \mathrm{mM}$ (Figure 5), indicating that at low concentrations of $\mathrm{NaCl}$, the repulsive interactions between the dispersed droplets were still strong enough to maintain the physical stability of the bilayer emulsion (Figure 4a). At higher salt concentrations, the emulsions phase separated (Figure 6), and the average droplet size was increased (Figure 4b). This observation was attributed to a reduced electrostatic repulsion among dispersed droplets as a result of charge screening (Figure 4a). ${ }^{[5,40]}$ The higher salt concentrations also reduced the electrostatic attraction between the WPI and WSPG, which opposes the formation of a bilayer emulsion (discussed later in section 3.4). Bridging flocculation can also be promoted by salt and might also contribute. ${ }^{[41]}$ In conclusion, the decrease in the zeta-potential of bilayer emulsions (from -26 to $-5 \mathrm{mV}$ ) with increasing the $\mathrm{NaCl}$ concentration can be attributed to one or more events including: electrostatic screening, ion binding, polysaccharide rearrangement, and polysaccharide desorption. ${ }^{[5]}$

With respect to the influence of ion type, we found that $\mathrm{CaCl}_{2}$ was more effective than $\mathrm{NaCl}$ in increasing the emulsion droplet size, and in decreasing zeta potential and hence was more effective in promoting phase separation and physical instability (Figures 5 and 6) Indeed, multivalent counter-ions (e.g., $\mathrm{Ca}^{2+}$ ) are much more effective at screening electrostatic interactions than monovalent counter-ions (e.g., $\mathrm{Na}^{+}$). Hence equivalent concentrations of multivalent ions screen more charges than monovalent counter-ions. Multivalent counter-ions can also attach to the surface of polyelectrolytes and lead to ion bridging. ${ }^{[1,5]}$

The creaming behavior of the WPI/WSPG stabilized emulsions for various salt concentrations after 7 days of storage is shown in Figure 5. The creaming index values of emulsions containing $\mathrm{CaCl}_{2}$ was higher at all salt levels than $\mathrm{NaCl}$. Photographs of all emulsions containing both salts were also taken (Figure 6). For $\mathrm{NaCl}$ samples the serum layer formed due to creaming was transparent at $150 \mathrm{mM}$ $\mathrm{NaCl}$ and above, while for the $\mathrm{CaCl}_{2}$ it was already transparent at $100 \mathrm{mM} \mathrm{CaCl}_{2}$. Also, for $\mathrm{CaCl}_{2}$ a sharper boundary was formed between the serum layer and the top layer. Generally, a much sharper border and a more clear serum layer were observed in the salt containing samples, most likely due to a larger degree of droplet flocculation. ${ }^{[39]}$ 

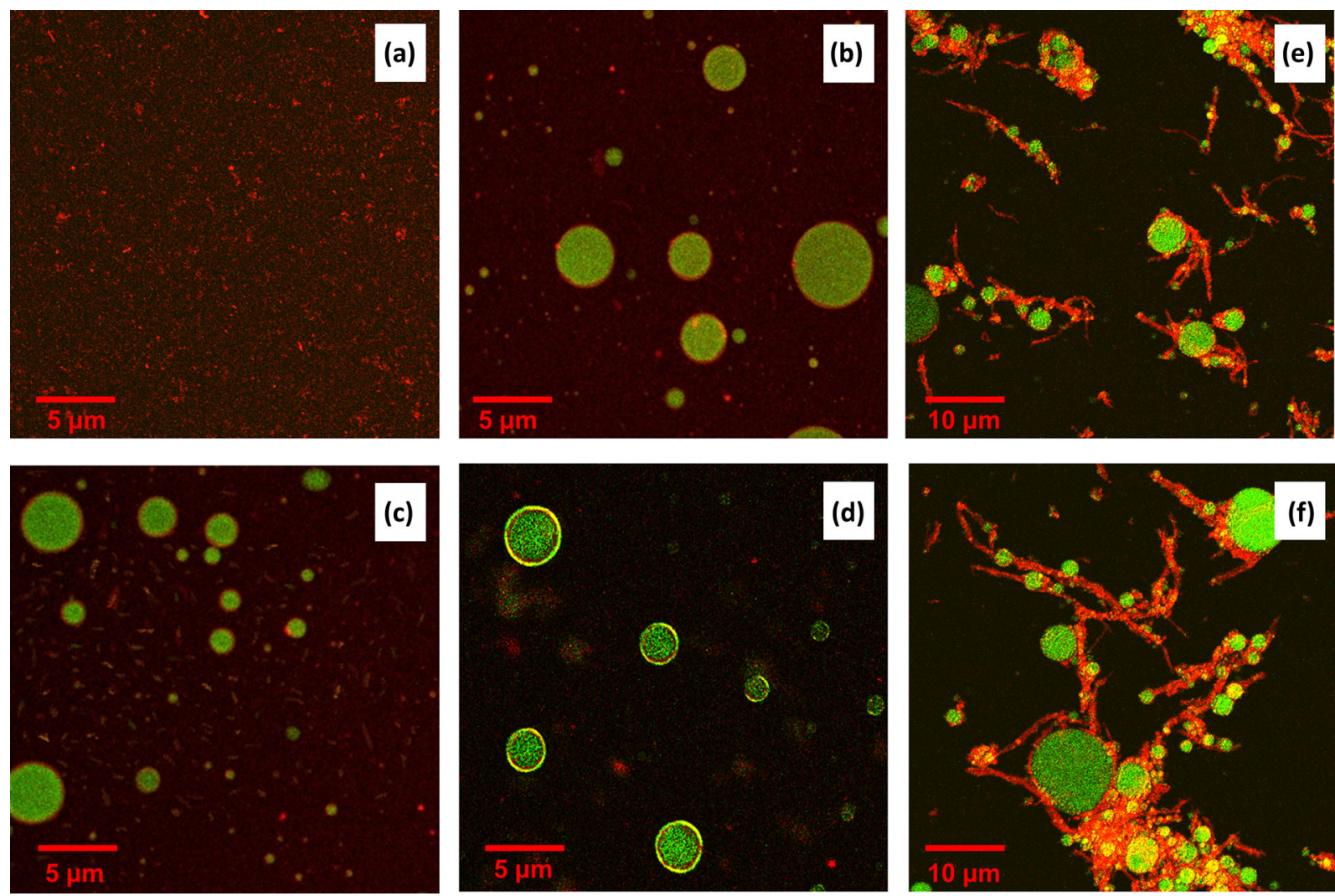

Figure 7. Confocal laser scanning micrographs (CLSM) of (a) WPI solution, (b) WPI emulsion at pH 7.0, (c) WPI/WSPG emulsion at pH 7.0, (d) WPI/WSPG emulsion at $\mathrm{pH}$ 5.0. WPI/WSPG emulsion in presence of (e) $100 \mathrm{mM} \mathrm{NaCl}$ and (f) $100 \mathrm{mM} \mathrm{CaCl}$.

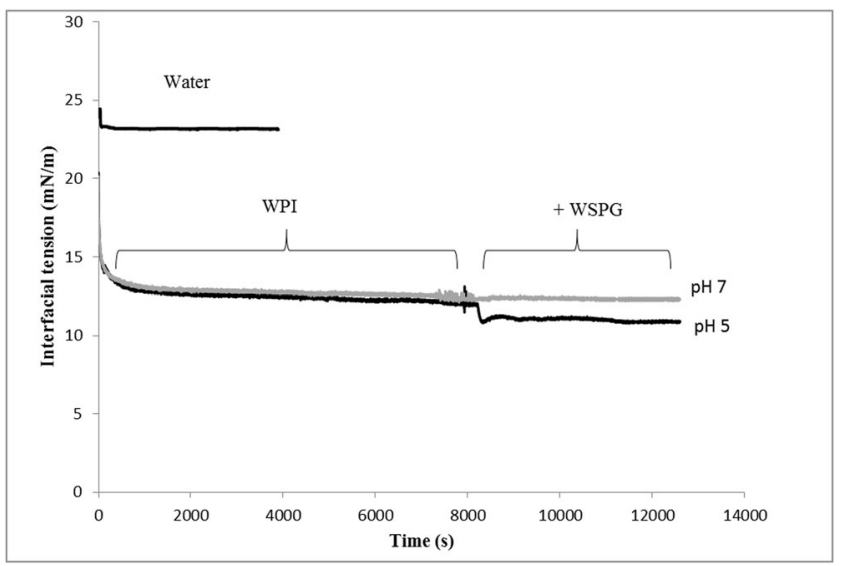

Figure 8. Interfacial tension as a function of WPI and WSPG adsorption in time at $\mathrm{pH}$ values of 7.0 and 5.0 .

\subsection{Confocal laser scanning microscopy}

To further investigate the formation of bilayer emulsions, confocal laser scanning microscopy was used. Figure $7 \mathrm{a}$ and $7 \mathrm{~b}$ show micrographs of WPI dispersions and WPI-stabilized $\mathrm{O} / \mathrm{W}$ emulsions at $\mathrm{pH}$ 7.0, respectively. As can be seen, the oil droplets (green) stained by nile red were uniformly covered with WPI (red) stained by nile blue. To demonstrate the formation of a second layer around the WPI-covered emulsions droplets, WSPG, labeled with 5Carboxyfluorescein $\mathrm{N}$-succinimidyl, was added to the WPIstabilized monolayer emulsion followed by $\mathrm{pH}$ adjustment. Figure $7 \mathrm{c}$ and $7 \mathrm{~d}$ show the confocal micrographs at $\mathrm{pH} 7.0$ and 5.0, respectively. As was also evident from other measurements, the CSLM images demonstrated that electrostatic attraction between WPI and WSPG at pH 5.0 led to the formation of bilayer emulsion (Figure $7 \mathrm{~d}$ ): a thick yellow green layer of WSPG around the WPI-coated oil droplets was observed. As expected, coating of the emulsion droplets with a thick WSPG layer did not occur at pH 7.0 (Figure 7c). CSLM was also used to visualize the influence of salt. A representative images for $100 \mathrm{mM} \mathrm{NaCl}$ is shown in Figure 7e, and a representative image for $100 \mathrm{mM} \mathrm{CaCl}_{2}$ in Figure $7 \mathrm{f}$. Consistent with our previous results, CSLM demonstrated that $\mathrm{CaCl}_{2}$ led to more extensive flocculation than $\mathrm{NaCl}$.

\subsection{Drop tensiometry}

Layers of WPI and WSPG at pH 7.0 and 5.0 were deposited at the oil-water interface (from the water side) using an automated drop tensiometer. Figure 8 shows the changes of interfacial tension as a function of adsorption time. First, WPI was injected. After approximately $2 \mathrm{~h}$, a limiting interfacial tension of $12.30 \mathrm{mN} / \mathrm{m}$ was reached, completely consistent with the expected behavior for proteins adsorbing to oil-water interfaces, ${ }^{[42,43]}$ and more specifically, WPI adsorbing to oil-water interfaces. ${ }^{[44]}$ During an intermediate rinsing step, the interfacial tension remained practically constant, demonstrating that there was very little desorption, supporting the common notion that this type of protein typically adsorbs irreversibly at the oil-water interfaces. ${ }^{[5]}$ Next, the WSPG was injected, initially at $\mathrm{pH}$ 7.0. Adding WSPG at pH 7.0 did not lead to any noticeable changes in 


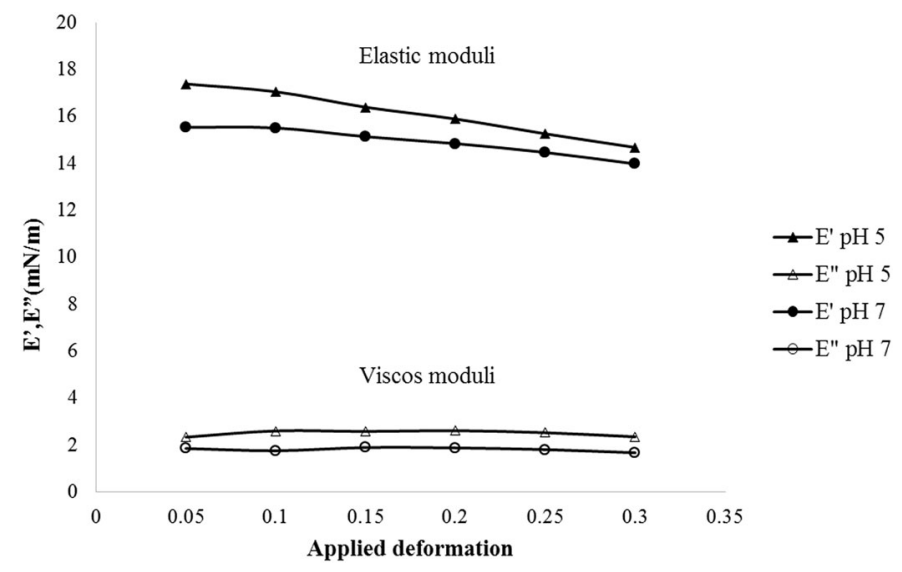

Figure 9. Dilatational elastic $\left(E^{\prime}\right)$ and viscous $\left(E^{\prime \prime}\right)$ moduli as a function of the applied deformation. Comparing interfacial behavior of WPI and WSPG adsorbed layers at pH values of 5.0 and 7.0 at room temperature.

the interfacial tension suggesting no adsorption to the WPI layer or any effect on the interface. However, when adding the WSPG at $\mathrm{pH} 5.0$, a slight but significant drop in the interfacial tension was observed, again in agreement with our earlier observations that indicated no interaction between WPI and WSPG at $\mathrm{pH}$ 7.0, and an associative interaction at $\mathrm{pH}$ 5.0.

Next, dilatational rheology was used to quantitate the mechanical properties of the WPI/WSPG layers at the oilwater interface. Elastic and viscous moduli were determined and results are shown in Figure 9. The data shows that the elastic modulus was much higher than the viscous modulus for both $\mathrm{pH}$ values of 7.0 and 5.0. This is known to be a common behavior of protein systems. ${ }^{[46]}$ For both cases, the elastic modulus decreased with increasing deformation whereas the viscous modulus was essentially constant. The WSPG adsorbed sample (at $\mathrm{pH}$ 5.0) was has an elastic modulus that is only somewhat slightly higher than that of the $\mathrm{pH} 7$ sample. This may be caused by the adsorption of the WSPG layer to the WPI at $\mathrm{pH}$ 5.0. A significant correlation between WSPG-WPI interaction and the measured interfacial tension was found in this study. However, this interaction did not reveal a strong effect on the mechanics of the interfacial layer. Indeed, from the literature, it seems that the effect of adsorbed polysaccharides on protein layers at the oil-water interface, varies from system to system. For multilayer systems, an increase in dilatational elasticity of protein polysaccharide multilayers (as compared to single protein layers) has been reported by a number of authors. ${ }^{[47,48]}$ However, other groups have also observed decreased elasticity, ${ }^{[49]}$ or no noticeable change in the elasticity upon complexation with polysaccharides, ${ }^{[50]}$ as we have found here.

\section{Conclusion}

In this study, we evaluated the ability of the water soluble fraction of Persian gum (WSPG), to prevent flocculation of oil-in-water emulsions stabilized by whey proteins, at $\mathrm{pH}$ values around their isoelectric point ( $\mathrm{pH}$ 5.0). Double layer emulsions were prepared by acidifying WPI-stabilized emulsions in the presence of WSPG molecules. Adsorption of WSPG to WPI-layers at oil-water interfaces at $\mathrm{pH} 5.0$ (but not $\mathrm{pH}$ 7.0) was confirmed using both CSLM and droplet tensiometry. Emulsions at $1 \mathrm{wt} \%$ WSPG and $\mathrm{pH} 5.0$ had very good long-term stability. The stability of $\mathrm{pH} 5$ WPI/WSPG double layer emulsions to ionic strength was not extremely good and ionic strengths above $75 \mathrm{mM}$ destabilized the double layer emulsions. This leaves ample room however, for the application of this novel stabilizer combination for weakly acidic emulsions in the food industry, as well as for the fabrication of delivery systems for bioactive compounds.

\section{Disclosure statement}

The authors declare that they have no competing interests.

\section{Funding}

This work was financially supported by University of Tehran (grant no. 5100588).

\section{Availability of data and material}

All data are available.

\section{Code availability}

Not applicable.

\section{Authors' contributions}

Mohammad Hadian was responsible for the experiment part and writing the manuscript. All authors contributed to the study conception and design. All authors read and approved the final manuscript.

\section{References}

[1] McClements, D. J. Food Emulsions: Principles, Practices, and Techniques; CRC Press: Boca Raton, FL, 2015.

[2] Stauffer, C. E. Emulsifiers, Eagan Press: St. Paul, MN, 1999.

[3] Charalambous, G.; Doxastakis, G. Food Emulsifiers: Chemistry, Technology, Functional Properties and Applications. Elsevier: Amsterdam, 1989.

[4] Dickinson, E. Hydrocolloids as Emulsifiers and Emulsion Stabilizers. Food Hydrocoll. 2009, 23, 1473-1482. DOI: 10.1016/ j.foodhyd.2008.08.005.

[5] Guzey, D.; McClements, D. J. Formation, Stability and Properties of Multilayer Emulsions for Application in the Food Industry. Adv. Colloid Interface Sci. 2006, 128-130, 227-248. DOI: 10.1016/j.cis.2006.11.021.

[6] Acevedo-Fani, A.; Silva, H. D.; Soliva-Fortuny, R.; MartínBelloso, O.; Vicente, A. A. Formation, Stability and Antioxidant Activity of Food-Grade Multilayer Emulsions Containing Resveratrol. Food Hydrocoll. 2017, 71, 207-215. DOI: 10.1016/j. foodhyd.2017.05.007.

[7] Benjamin, O.; Silcock, P.; Leus, M.; Everett, D. Multilayer Emulsions as Delivery Systems for Controlled Release of Volatile Compounds Using $\mathrm{pH}$ and Salt Triggers. Food Hydrocoll. 2012, 27, 109-118. DOI: 10.1016/j.foodhyd.2011.08.008. 
[8] Fioramonti, S. A.; Martinez, M. J.; Pilosof, A. M.; Rubiolo, A. C.; Santiago, L. G. Multilayer Emulsions as a Strategy for Linseed Oil Microencapsulation: Effect of $\mathrm{pH}$ and Alginate Concentration. Food Hydrocoll. 2015, 43, 8-17. DOI: 10.1016/j. foodhyd.2014.04.026.

[9] Shamsara, O.; Jafari, S. M.; Muhidinov, Z. K. Development of Double Layered Emulsion Droplets with Pectin/ $\beta$-Lactoglobulin Complex for Bioactive Delivery Purposes. J. Mol. Liq. 2017, 243, 144-150. DOI: 10.1016/j.molliq.2017.08.036.

[10] Esfanjani, A. F.; Jafari, S. M.; Assadpoor, E.; Mohammadi, A. NanoEncapsulation of Saffron Extract through Double-Layered Multiple Emulsions of Pectin and Whey Protein Concentrate. J. Food Eng. 2015, 165, 149-155. DOI: 10.1016/j.jfoodeng.2015.06.022.

[11] Chang, Y.; Hu, Y.; McClements, D. J. Competitive Adsorption and Displacement of Anionic Polysaccharides (Fucoidan and Gum Arabic) on the Surface of Protein-Coated Lipid Droplets. Food Hydrocoll. 2016, 52, 820-826. DOI: 10.1016/j.foodhyd. 2015.08.023.

[12] Dickinson, E. Milk Protein Interfacial Layers and the Relationship to Emulsion Stability and Rheology. Colloids Surf. $B$ Biointerfaces 2001, 20, 197-210. DOI: 10.1016/S09277765(00)00204-6.

[13] Kerstens, S.; Murray, B. S.; Dickinson, E. Microstructure of $\beta$-Lactoglobulin-Stabilized Emulsions Containing Non-Ionic Surfactant and Excess Free Protein: Influence of Heating. J. Colloid Interface Sci. 2006, 296, 332-341. DOI: 10.1016/j.jcis. 2005.08.046.

[14] Dalgleish, D. G. Conformations and Structures of Milk Proteins Adsorbed to Oil-Water Interfaces. Food Res. Int. 1996, 29, 541-547. DOI: 10.1016/S0963-9969(96)00065-8.

[15] Ye, A. Surface Protein Composition and Concentration of Whey Protein Isolate-Stabilized Oil-in-Water Emulsions: Effect of Heat Treatment. Colloids Surf. B Biointerfaces 2010, 78, 24-29. DOI: 10.1016/j.colsurfb.2010.02.001.

[16] Jiang, S.; Altaf Hussain, M.; Cheng, J.; Jiang, Z.; Geng, H.; Sun, Y.; Sun, C.; Hou, J. Effect of Heat Treatment on Physicochemical and Emulsifying Properties of Polymerized Whey Protein Concentrate and Polymerized Whey Protein Isolate. LWT 2018, 98, 134-140. DOI: 10.1016/j.lwt.2018.08.028.

[17] Schröder, A.; Berton-Carabin, C.; Venema, P.; Cornacchia, L. Interfacial Properties of Whey Protein and Whey Protein Hydrolysates and Their Influence on O/W Emulsion Stability. Food Hydrocoll. 2017, 73, 129-140. DOI: 10.1016/j.foodhyd.2017.06.001.

[18] Dabestani, M.; Kadkhodaee, R.; Phillips, G. O.; Abbasi, S. Persian Gum: A Comprehensive Review on Its Physicochemical and Functional Properties. Food Hydrocoll. 2018, 78, 92-99. DOI: $10.1016 /$ j.foodhyd.2017.06.006.

[19] Hadian, M.; Hosseini, S. M. H.; Farahnaky, A.; Mesbahi, G. R. Optimization of Functional Nanoparticles Formation in Associative Mixture of Water-Soluble Portion of Farsi Gum and Beta-Lactoglobulin. Int. J. Biol. Macromol. 2017, 102, 1297-1303. DOI: 10.1016/j.ijbiomac.2017.05.022

[20] Abbasi, S. Challenges towards Characterization and Applications of a Novel Hydrocolloid: Persian Gum. Curr. Opin. Colloid Interface Sci. 2017, 28, 37-45. DOI: 10.1016/j. cocis.2017.03.001.

[21] Abbasi, S.; Rahimi, S. Persian Gum. In Encyclopedia of Biomedical Polymers and Polymeric Biomaterials, Mishra, S., Ed. CRC Press: Boca Raton, FL, 2015; pp 9001-9011.8.

[22] Fadavi, G.; Mohammadifar, M. A.; Zargarran, A.; Mortazavian, A. M.; Komeili, R. Composition and Physicochemical Properties of Zedo Gum Exudates from Amygdalus Scoparia. Carbohydr. Polym. 2014, 101, 1074-1080. DOI: 10.1016/j.carbpol.2013.09.095.

[23] Hadian, M.; Hosseini, S. M. H.; Farahnaky, A.; Mesbahi, G. R.; Yousefi, G. H.; Saboury, A. A. Isothermal Titration Calorimetric and Spectroscopic Studies of $\beta$-LactoglobulinWater-Soluble Fraction of Persian Gum Interaction in Aqueous Solution. Food Hydrocoll. 2016, 55, 108-118. DOI: 10.1016/j. foodhyd.2015.11.006.
[24] Khalesi, H.; Emadzadeh, B.; Kadkhodaee, R.; Fang, Y. Effects of Biopolymer Ratio and Heat Treatment on the Complex Formation between Whey Protein Isolate and Soluble Fraction of Persian Gum. J. Dispers. Sci. Technol. 2017, 38, 1234-1241. DOI: $10.1080 / 01932691.2016 .1230064$.

[25] Golkar, A.; Nasirpour, A.; Keramat, J. $\beta$-Lactoglobulin-Angum Gum (Amygdalus Scoparia Spach) Complexes: Preparation and Emulsion Stabilization. J. Dispers. Sci. Technol. 2015, 36, 685-694. DOI: 10.1080/01932691.2014.919587.

[26] Sepeidnameh, M.; Hosseini, S. M. H.; Niakosari, M.; Mesbahi, G. R.; Yousefi, G. H.; Golmakani, M.-T.; Nejadmansouri, M. Physicochemical Properties of Fish Oil in Water Multilayer Emulsions Prepared by a Mixture of Whey Protein Isolate and Water-Soluble Fraction of Farsi Gum. Int. J. Biol. Macromol. 2018, 118, 1639-1647. DOI: 10.1016/j.ijbiomac.2018.07.007.

[27] Keowmaneechai, E.; McClements, D. Influence of EDTA and Citrate on Physicochemical Properties of Whey ProteinStabilized Oil-in-Water Emulsions Containing CaCl2. J. Agric. Food Chem. 2002, 50, 7145-7153. DOI: 10.1021/jf020489a.

[28] Benjamins, J.; Cagna, A.; Lucassen-Reynders, E. Viscoelastic Properties of Triacylglycerol/Water Interfaces Covered by Proteins. Colloids Surf. Physicochem. Eng. Asp. 1996, 114, 245-254. DOI: 10.1016/0927-7757(96)03533-9.

[29] Demetriades, K.; McClements, D. J. Influence of $\mathrm{pH}$ and Heating on Physicochemical Properties of Whey Protein-Stabilized Emulsions Containing a Nonionic Surfactant. J. Agric. Food Chem. 1998, 46, 3936-3942. DOI: 10.1021/jf980463c.

[30] Charoen, R.; Jangchud, A.; Jangchud, K.; Harnsilawat, T.; Naivikul, O.; McClements, D. J. Influence of Biopolymer Emulsifier Type on Formation and Stability of Rice Bran Oilin-Water Emulsions: Whey Protein, Gum Arabic, and Modified Starch. J. Food Sci. 2011, 76, E165-E172. DOI: 10.1111/j.17503841.2010.01959.x.

[31] Qiu, C.; Zhao, M.; McClements, D. J. Improving the Stability of Wheat Protein-Stabilized Emulsions: Effect of Pectin and Xanthan Gum Addition. Food Hydrocoll. 2015, 43, 377-387. DOI: 10.1016/j.foodhyd.2014.06.013.

[32] Dickinson, E. Interfacial Structure and Stability of Food Emulsions as Affected by Protein-Polysaccharide Interactions. Soft Matter 2008, 4, 932-942. DOI: 10.1039/b718319d.

[33] Weinbreck, F.; De Vries, R.; Schrooyen, P.; De Kruif, C. Complex Coacervation of Whey Proteins and Gum Arabic. Biomacromolecules 2003, 4, 293-303. DOI: 10.1021/bm025667n.

[34] Turgeon, S. L.; Laneuville, S. I. Protein + Polysaccharide Coacervates and Complexes: From Scientific Background to Their Application as Functional Ingredients in Food Products. In Modern Biopolymer Science; Kasapis, S., Norton, I. T., Ubbink J. B., Eds.; Elsevier: San Diego, CA, 2009; pp 327-363.

[35] Pongsawatmanit, R.; Harnsilawat, T.; McClements, D. J. Influence of Alginate, $\mathrm{pH}$ and Ultrasound Treatment on Palm Oil-in-Water Emulsions Stabilized by $\beta$-Lactoglobulin. Colloids Surf. Physicochem. Eng. Asp. 2006, 287, 59-67. DOI: 10.1016/j. colsurfa.2006.03.022.

[36] Pallandre, S.; Decker, E.; McClements, D. Improvement of Stability of Oil-in-Water Emulsions Containing CaseinateCoated Droplets by Addition of Sodium Alginate. J. Food Sci. 2007, 72, E518-E524. DOI: 10.1111/j.1750-3841.2007.00534.x.

[37] Dickinson, E. Hydrocolloids at Interfaces and the Influence on the Properties of Dispersed Systems. Food Hydrocoll. 2003, 17, 25-39. DOI: $10.1016 / \mathrm{S} 0268-005 \mathrm{X}(01) 00120-5$.

[38] Wang, Y.; Li, D.; Wang, L.-J.; Adhikari, B. The Effect of Addition of Flaxseed Gum on the Emulsion Properties of Soybean Protein Isolate (SPI). J. Food Eng. 2011, 104, 56-62. DOI: 10.1016/j.jfoodeng.2010.11.027.

[39] Santipanichwong, R.; Suphantharika, M. Influence of Different $\beta$-Glucans on the Physical and Rheological Properties of Egg Yolk Stabilized Oil-in-Water Emulsions. Food Hydrocoll. 2009, 23, 1279-1287. DOI: 10.1016/j.foodhyd.2008.10.006.

[40] Niu, F.; Zhou, J.; Niu, D.; Wang, C.; Liu, Y.; Su, Y.; Yang, Y. Synergistic Effects of Ovalbumin/Gum Arabic Complexes on the 
Stability of Emulsions Exposed to Environmental Stress. Food Hydrocoll. 2015, 47, 14-20. DOI: 10.1016/j.foodhyd.2015.01.002.

[41] Xu, X.; Luo, L.; Liu, C.; McClements, D. J. Utilization of Anionic Polysaccharides to Improve the Stability of Rice Glutelin Emulsions: Impact of Polysaccharide Type, pH, Salt, and Temperature. Food Hydrocoll. 2017, 64, 112-122. DOI: 10. 1016/j.foodhyd.2016.11.005.

[42] Benjamins, J.; Lyklema, J.; Lucassen-Reynders, E. Compression/ Expansion Rheology of Oil/Water Interfaces with Adsorbed Proteins. Comparison with the Air/Water Surface. Langmuir 2006, 22, 6181-6188. DOI: 10.1021/la060441h.

[43] Maldonado-Valderrama, J.; Woodward, N. C.; Gunning, A. P.; Ridout, M. J.; Husband, F. A.; Mackie, A. R.; Morris, V. J.; Wilde, P. J. Interfacial Characterization of Beta-Lactoglobulin Networks: Displacement by Bile Salts. Langmuir 2008, 24, 6759-6767. DOI: 10.1021/la800551u.

[44] Corstens, M. N.; Osorio Caltenco, L. A.; de Vries, R.; Schroën, K.; Berton-Carabin, C. C. Interfacial Behaviour of Biopolymer Multilayers: Influence of In Vitro Digestive Conditions. Colloids Surf B Biointerfaces 2017, 153, 199-207. DOI: 10.1016/j.colsurfb.2017.02. 019 .

[45] Miller, R.; Grigoriev, D.; Krägel, J.; Makievski, A.; MaldonadoValderrama, J.; Leser, M.; Michel, M.; Fainerman, V. Experimental Studies on the Desorption of Adsorbed Proteins from Liquid Interfaces. Food Hydrocoll. 2005, 19, 479-483. DOI: $10.1016 /$ j.foodhyd.2004.10.012.

[46] Bos, M. A.; van Vliet, T. Interfacial Rheological Properties of Adsorbed Protein Layers and Surfactants: A Review. Adv. Colloid Interface Sci. 2001, 91, 437-471. DOI: 10.1016/S00018686(00)00077-4.

[47] Jourdain, L. S.; Schmitt, C.; Leser, M. E.; Murray, B. S.; Dickinson, E. Mixed Layers of Sodium Caseinate + Dextran Sulfate: Influence of Order of Addition to Oil-Water Interface. Langmuir 2009, 25, 10026-10037. DOI: 10.1021/la900919w.

[48] Schmitt, C.; Palma da Silva, T.; Bovay, C.; Rami-Shojaei, S.; Frossard, P.; Kolodziejczyk, E.; Leser, M. E. Effect of Time on the Interfacial and Foaming Properties of Beta-Lactoglobulin/ Acacia Gum Electrostatic Complexes and Coacervates at $\mathrm{pH}$ 4.2. Langmuir 2005, 21, 7786-7795. DOI: 10.1021/la0510984.

[49] Ganzevles, R. A.; Kosters, H.; van Vliet, T.; Cohen Stuart, M. A.; de Jongh, H. H. Polysaccharide Charge Density Regulating Protein Adsorption to Air/Water Interfaces by Protein/Polysaccharide Complex Formation. J. Phys. Chem. B 2007, 111, 12969-12976. DOI: 10.1021/jp075441k.

[50] Zinoviadou, K. G.; Scholten, E.; Moschakis, T.; Biliaderis, C. G. Properties of Emulsions Stabilised by Sodium Caseinate-Chitosan Complexes. Int. Dairy J. 2012, 26, 94-101. DOI: 10.1016/j.idairyj.2012.01.007. 